Vasco Almeida

Instituto Superior Miguel Torga

e-mail: vascoalmeida@ismt.pt

\title{
The Moral and Political Dimension of Economics The Fact-Value Dichotomy
}

\begin{abstract}
Since the neoclassical school, the separation between facts and values, is and ought, positive and normative, has become a concern in conventional economic analyses. Economics should focus on facts, and present general principles, leaving the choice of various technical alternatives to policy makers. This article addresses the following questions: can economics, seen as a positive science, be separated from the political dimension? Is it possible to separate facts from values or are they necessarily intertwined?

After showing how the separation between economics and moral philosophy unfolded throughout the history of economic thought, the article analyses the factvalue dichotomy discussion and concludes that facts and values are necessarily intertwined. Then, the article shows that the premises and theories of conventional economic theories contain hidden values, despite being presented as universal truths on which policies are based, and thus fail to discuss the various perspectives of the problems.

Reviving a tradition commenced by Aristotle, the article concludes by arguing that economics is necessarily moral and political. However, the acknowledgement of the normative nature of economics cannot compromise the pursuit of objectivity.
\end{abstract}

Keywords: economics, political economy, fact-value dichotomy

JEL Classification: A13, B41 


\section{Introduction}

The emergence of the neoclassical school in the late $19^{\text {th }}$ century marks a definite break with a long tradition, which from Aristotle to Adam Smith perceived economic science as a branch of moral philosophy, and necessarily had an ethical and political dimension. In fact, the actual denomination of this discipline used by the English classical school - political economy - mirrored the idea that economics was a branch of moral philosophy that dealt with issues such as production, distribution, and wealth.

The neoclassical authors, highly fascinated by the progress in physical sciences throughout the eighteen-hundreds and the positivist approaches of science, endeavoured to turn the discipline into an objective, value-neutral science, detached from the ends. The term which has been used by orthodox economists since Alfred Marshall to name the discipline - economics - thus removing the political dimension, mirrors that perspective. Economics should focus on facts and present general principles, leaving the choice of various technical alternatives to policy makers. The separation between facts and values, is and ought, positive and normative, became a concern in conventional economic analyses.

This article is based on these considerations and seeks to address the following questions: can economics, seen as a positive science, be separated from the political dimension? Is it possible to separate facts from values or are they necessarily intertwined?

To address these questions, this text is structured as follows: after this introduction, the second section describes how the separation between economics and moral philosophy unfolded throughout the history of economic thought, from Aristotle to contemporary authors. The third section analyses the arguments in favour of a separation between facts and values, based on the idea that economics should study the positive facts, thus leaving normative considerations to political science. The critiques to the fact-value dichotomy, which emerged from various fields of social sciences, are presented in the fourth section, followed by an explanation of how conventional economic analyses, presented as 'value-free,' are inevitably based on normative considerations, in the fifth section. Finally, the answers to the key questions of this article are presented in the last section.

\section{The separation between economics and moral philosophy}

The term 'economics' had its origin in Ancient Greece. Etymologically, it results from the combination of the words oikos (house, property) and nomos (law, norm, rule), and it can be understood as the rules of the house, ${ }^{1}$ or, in a wider sense, as the science of laws of home economics. ${ }^{2}$ However, it would be imprudent to sup-

\footnotetext{
${ }^{1}$ F. Louçã, C. Caldas., Economia(s), Afrontamento, Porto 2010, p. 16.

${ }^{2}$ A. Nunes, Noção e objeto de Economia Politica, Almedina, Coimbra 2013, p. 15.
} 
pose, like some historians of economic thought believe, ${ }^{3}$ that according to Greek philosophers the study of economics was limited to housekeeping, including the management of materials goods and human resources, i.e., family members and slaves.

In fact, a careful reading of the two works by Aristotle - Nicomachean Eth$i c s,{ }^{4}$ and Politics, ${ }^{5}$ - that address economic issues, leaves no room for doubt that the meaning of some of the economic concepts therein is broader than that given by historians of economic thought. More importantly, some of the ideas developed by Aristotle are still current, as is explained hereinafter.

In a passage from Politics, ${ }^{6}$ Aristotle distinguishes between economics, perceived as the utilisation of wealth, and chrematistics, defined as the way of obtaining wealth. Aristotle, however, distinguished between two types of chrematistics: natural, subordinate to economics, and non-subordinate to economics, which aimed at the unlimited pursuit of wealth. The former, of the domestic type, necessary and recommended, aimed at the limited acquisition of wealth, with a view to creating the material conditions for a happy life, the Good Life at the Polis; the latter, of a commercial nature, was based on the unlimited accumulation of wealth. Aristotle considered it to be anti-natural and, therefore, should be condemned, since the pursuit and unlimited accumulation of wealth would always be done at the expense of some.

Therefore, economics as knowledge is the art of using what is necessary for domestic life and the Good Life at the Polis. The notion of Good Life has a very specific moral meaning: it is a life of virtue through which individuals in a community attain happiness. In other words, the human being is essentially political, and the polis is the place where individuals feel completely fulfilled. Right at the start of Nicomachean Ethics, Aristotle stated that politics, the most noble of sciences, or as he puts it the 'master art,' determines:

Which of the sciences should be studied in a state, and which each class of citizens should learn and up to what point they should learn them (...) now, since politics uses the rest of the sciences, and since, again, it legislates as to what we are to do and what we are to abstain from, the end of this science must include those of the others, so that this end must be the good for man. ${ }^{7}$

In short, for Aristotle economics is thus linked to the study of ethics and politics, an idea he would develop further in Politics.

In the $13^{\text {th }}$ century, when Aristotle was rediscovered in Europe, Nicomachean Ethics was one of the principle texts used by scholastics in their studies. Within the Aristotelian logic, economics was still considered part of ethics and politics. Thus,

\footnotetext{
${ }^{3}$ R. Crespo, On Aristotle and Economics, "Working Paper Series IAE" 2008, https://www.iae.edu.ar/pi /Documentos\%20Investigacin/Working\%20Papers/DTIAE08_2008.pdf (accessed: February 9, 2014).

${ }^{4}$ Aristotle, Nicomachean Ethics, Cambridge University Press, Cambridge 2000.

${ }^{5}$ Aristotle, Politics, ed. B. Jowet, 1885, Online Library of Liberty, http://oll.libertyfund.org/titles/579 (accessed: January 23, 2014).

${ }^{6}$ Ibidem, pp. 15-17.

${ }^{7}$ Aristotle, Nicomachean..., p. 4.
} 
scholastic economics was developed through the study of moral philosophy. For example, the debate on the legitimacy of interest was always based on moral considerations. ${ }^{8}$

Scholastic economics was highly influential throughout centuries. It was still being taught as part of a branch of moral philosophy in eighteenth-century European universities. When Adam Smith became chair of moral philosophy at the University of Glasgow, he divided the course into four parts: natural theology, ethics, justice, and political regulations, all of which aimed to achieve prosperity and the wealth of the nations. Adam Smith and other Scottish Enlightenment philosophers eventually adopted the term political economy to name the branch of moral philosophy which addressed the issues of production, consumption, and circulation of wealth.

Some authors consider that The Wealth of Nations, Adam Smith's magnum opus published in $1776,{ }^{9}$ breaks off with moral philosophy as it is based on an individualistic, selfish conception of the human being. Numerous authors have recently shown that this is a limited view on Smith's work. Before the publication of The Wealth of Nations, Adam Smith wrote in 1759 The Theory of Moral Sentiments,${ }^{10}$ which provided the underpinnings for his second work.

In fact, Smith carried out extensive revisions to his book throughout his life, showing the importance he gave to his first work. ${ }^{11}$ The Theory of Moral Sentiments, which generally corresponds to the second part of the moral philosophy course Smith taught at Glasgow, is an essay on the analysis of the principles according to which people judge conduct and character: firstly, that of their kin, then of themselves. Adam Smith presents a number of virtues, for example, justice, prudence, and benevolence, which have a corresponding economic manifestation in The Wealth of Nations. While justice is implicit in his analysis of free trade, prudence and benevolence are virtues which support the accumulation of capital and non-alienation, respectively, which results from the extreme division of labour. $^{12}$

The position of Adam Smith's successors regarding the relation between economics and moral philosophy is sometimes contradictory and ambiguous. For example, Malthus, the leading figure in economics after Adam Smith and the first professor of political economy in England, still perceived economics as a moral science. ${ }^{13}$ On the other hand, David Ricardo, who rapidly overshadowed Malthus after the publication of On the Principles of Political Economy and Taxation in

\footnotetext{
${ }^{8}$ J. Alvey, A Short History of Economics as a Moral Science, "Journal of Markets \& Morality" 1999, Vol. 2, No. 1, pp. 127-143.

${ }^{9}$ A. Smith, Riqueza das Nações, Fundação Calouste Gulbenkian, Lisboa 2001.

${ }^{10}$ Idem, Teoria dos Sentimentos Morais, Martins Fontes, São Paulo 2012.

${ }^{11}$ The Theory of Moral Sentiments was first published in 1759, and had a total of six editions. The original text was successively revised, and had its last revision in 1790, only a few months before Smith's death.

12 J. Alvey, op. cit., pp. 56-58.

${ }^{13}$ T. Malthus, Definitions in Political Economy, ed. J. Murray 1827, Online Library of Liberty, http:// oll.libertyfund.org/titles/2255 (accessed: December 16, 2014).
} 
$1817,{ }^{14}$ criticised Smith for his lack of acknowledgment that political economy is a 'strict science like mathematics.' ${ }^{15}$ Ricardo's position clearly differs from that of Adam Smith, as did John Stuart Mill's, the next leading economist of the classical school. Despite some ambiguity in his positions, Mill was the first to conceive the idea of homo oeconomicus, the optimiser of individual wellbeing, and to defend the practice of methods similar to those used in physical sciences in political economy. Mill argued that science should study what it is and what it ought to be. In other words, Mill believed that economics should be severed from philosophy, despite having constantly overstepped the boundaries between science and art throughout his work. ${ }^{16}$

However, the separation of economics and moral philosophy happened radically with the advent of the marginalist school, which would lay the basis of the neoclassical school. Various generations of neoclassical economists were fascinated by the advancements of physical sciences, and were definitely influenced by the growing importance of the positivist perspectives in science philosophy. For example, William Stanley Jevons, one of the founders of marginalism, dedicated his main work (The Theory of Political Economy, first published in 1871) to the defence of a mechanical and mathematical application to economics. As he states:

As all the physical sciences have their basis more or less obviously in the general principles of mechanics, so all branches and divisions of economic science must be pervaded by certain general principles. ${ }^{17}$

Unsurprisingly, in the second edition of his work he advocated the need to change political economy to economic science or economics.

However, it was only with Alfred Marshall that political economy became economics. His main work, Principles of Economics, published in $1890,{ }^{18}$ would be taught for decades in the main universities. As Professor at Cambridge, Marshall endeavoured to make economics an autonomous area and succeeded to do so in 1903, when the first course designed to train professionals was created.

Like Jevons, Marshall advocated an approach to physical sciences. With a strong academic background in mathematics, Marshall helped incorporate quantitative methods in economic analysis. However, despite being perceived as a strong opponent of economics as a moral science, Marshall's perspective should

\footnotetext{
${ }^{14}$ D. Ricardo, Princípios de Economia Política e Tributação, Fundação Calouste Gulbenkian, Lisboa 1983.

${ }^{15}$ Idem, The Works and Correspondence of David Ricardo, ed. P. Sraffa with the collaboration of M.H. Dobb, Cambridge University Press, Cambridge 1951-1973, VIII, p. 331.

${ }^{16}$ J.S. Mill, On the Definition and Method of Political Economy [in:] The Philosophy of Economics, ed. D. Hausman, Cambridge University Press, Cambridge 2008, pp. 41-58.

${ }^{17}$ W.S. Jevons, The Theory of Political Economy, Macmillan and Company, London 1888, Library of Economics and Liberty, p. 50, http://www.econlib.org/library/YPDBooks/Jevons/jvnPE.html (accessed: September 23, 2014).

${ }_{18}$ A. Marshall, Principles of Economics, Macmillan, London 1961.
} 
be analysed with some caution. For example, he believed that mathematics should be applied to economics, albeit with some restraint, as evidenced by one of his most cited quotes:

A good mathematical theorem dealing with economic hypotheses was very unlikely to be good economics: and I went more and more on the rules (1) Use mathematics as a short-hand language, rather than as an engine of inquiry. (2) Keep to them till you have done. (3) Translate into English. (4) Then illustrate by examples that are important in real life. (5) Burn the mathematics. (6) If you can't succeed in 4, burn 3. This last I did often. ${ }^{19}$

It should also be noted that, for Marshall, the concept of homo oeconomicus was rather simplistic, as he preferred to consider how the behaviour of the economic agents was determined by their sociocultural environment. He also expressed great concern for the social issues of his time, such as poverty and social inequality. In his opening lecture at Cambridge, he described his mission at university as follows:

To increase the numbers who Cambridge University sends out into the world with cool heads but warm hearts, willing to give some of their best powers to grappling with the social suffering around them; resolved not to rest content till they have opened up to all the material means of a refined and noble life. ${ }^{20}$

Thus, some of Marshall's moral and political concerns do not seem completely beyond the scope of economics.

However, the complete separation of economics from moral science happens with its conversion to positivism. The starting point is Lionel Robbins' 1932 seminal Essay on the Nature and Significance of Economic Science.

According to Robbins, economics is the science which studies 'the human behaviour as a relationship between limited resources and unlimited wants which have alternative uses. ${ }^{21}$ This definition, which still prevails in important textbooks and is taught all over the world, implies that economics should only focus on defining the means to the ends, which in turn are defined within the political sphere. Thus, according to Robbins, economics is neutral in relation to values, because it deals with verifiable facts, whereas ethics and politics deal with valorisations and obligations. As Robbins stated: 'it does not seem to associate the two studies (economics and ethics) in any form but mere juxtaposition. ${ }^{22}$

Robbins' position has been interpreted in the following way: let governments decide their objective function defined in terms of the multiple ends of economic activity; it is the task of economists to outline the possibility function, the costs

\footnotetext{
${ }^{19}$ A. Marshall, The Correspondence of Alfred Marshall [in:] Memorials of Alfred Marshall, ed. A.C. Pigou, Macmillan, London 1925, p. 427.

${ }^{20}$ Ibidem, p. 174.

${ }^{21}$ L. Robbins, An Essay of Nature and Significance of Economic Science, Macmillan and Co., London 1945 , p. 16.

${ }^{22}$ Ibidem, p. 148
} 
and benefits of alternative allocations of scarce resources; provided that the 'means-ends' distinction is maintained, economic advice to governments is, or rather can be, value-free. In this way, the role played by economists is that of a technocrat. The domain of factual statements is, thus, separated from the field of evaluative statements. This distinction is not new and given its importance to the objectives of this article it will be developed in the following section.

But before moving on to the next point, it should be added that, once again, original texts such as Robbins' Essay have been superficially and hastily interpreted. In truth, Robbins never denied the importance of economist's opinions on ethics and politics. He perceived normative economics as a return to the political economy of the classical authors. However, despite seeing normative economics as a relevant field of work, he considered it non-scientific. ${ }^{23}$

\section{The fact-value dichotomy in economic theory}

The idea of value-free science is nearly two-hundred years old, and dates back to David Hume, an important figure of the Scottish Enlightenment who, together with John Locke and George Berkeley, formed the core of British empiricism. In A Treatise of Human Nature, Hume states that ought cannot be severed from is, and purely factual descriptive statements can only involve other descriptive and factual statements, (never norms), formal ethical statements or indeed prescriptions to do something. ${ }^{24}$ The statement known as Hume's guillotine establishes a strict separation between facts and values, is and ought, positive and normative, objective and subjective, descriptive and prescriptive, science and art. ${ }^{25}$ A little later, Nassau Senior brought the distinction between positive and normative economics, which is still one of the subjects included in today's first chapters of economics textbooks. According to Senior, the conclusions of the economist "whatever be their generality and their truth do not authorize him in adding a single syllable of advice. That privilege belongs to the writer or the statesman. ${ }^{, 26}$ Later on, he reinforces his idea by stating that the role of the economist is neither to recommend nor neglect, but rather to establish general principles. Similarly, John Stuart Mill distinguished between art and economic science, and advocated methodological nomism when stating that economics should be developed in the same way as positivist sciences, such as geometry. ${ }^{27}$

John Neville Keynes resumed the subject of art and science in his famous three-part distinction: 1) positive science, a systematised body of knowledge which refers to what is, 2) normative science, the study of ought and 3) the art of pre-

${ }^{23}$ C. Caldas, V. Neves, The meaning of objectivity. What can we learn from Robbins and Myrdal [in:] Values and Objectivity in Economics, eds. J. Caldas, V. Neves, Routledge, London 2012, pp. 47-63.

${ }^{24}$ D. Hume, Treatise of Human Nature, Clarendon Press, Oxford 1888, http://michaeljohnsonphilosophy. com/wp-content/uploads/2012/01/5010_Hume_Treatise_Human_Nature.pdf. (accessed: September 24, 2014).

${ }^{25}$ M. Blaug, A Metodologia da Economia, Gradiva, Lisboa 1980.

${ }^{26}$ N. Senior, An Outline of the Science of Political Economy, Augustus Kelley, London 1965, p. 3.

${ }^{27}$ J.S. Mill, op. cit. 
cepts. ${ }^{28}$ A contemporary of Keynes, Weber advocated 'Wertfreiheit,' that is, freedom from value judgments. ${ }^{29}$ Weber believed in the possibility of a value-free science, but unlike many of his contemporaries he mistrusted methodological monism, as he saw significant differences between what he called cultural sciences (in which he included economics) and natural, exact sciences.

One last reference to the proponents of a value-free economics is due. Milton Friedman influenced generations of economists, and in 1953 wrote one of the bestknown texts on the methodology of economics. ${ }^{30}$ Friedman presented the following argument: from the moment we have objective access to the empirical world through our sensorial experience, scientists do not have to be concerned about what ought to be.

Indeed, and together with Hume's guillotine, it is still one of the most frequently used ideas to support value-free economics, ${ }^{31}$ albeit the higher level of sophistication of subsequent arguments on the neutrality of science. For example, Blaug, in defence of a Lakatosian falsificationism influenced by Coats ${ }^{32}$ and Hutchinson, ${ }^{33}$ divided economic science into three components: pre-scientific decisions, scientific analysis, and post-scientific application. Coats and Hutchinson argued that, although the first and third components were contaminated by values, the field of science remains pure, i.e., value-free. Blaug, however, maintained that values can permeate scientific analysis. Nevertheless, he makes a distinction between characterising and evaluating value judgments. While the former expressed an estimate of the extent to which any type of action, object or institution is embedded in a given context, the latter expressed approval or disapproval of a moral ideal or an action based thereon. Therefore, the purpose of this distinction is to show that there are value judgments which do not have an ethical meaning, and only which enable the development of science.

\section{Criticism of the fact-value dichotomy}

The arguments in favour of the fact-value dichotomy and neutral science are presented with varying degrees of sophistication. Recently, however, they have received growing criticism from various fields. Also, it is understood that this criticism is expressed by those who attack the supporting currents of philosophy of science, such as logical empiricism and Popper's falsificationism.

\footnotetext{
${ }^{28}$ J.N. Keynes, The Scope and the Method of Political Economy, Batoche Books, Kitchener 1990.

${ }^{29}$ M. Weber, Objectivity and Understanding in Economics [in:] The Philosophy of Economics, ed. D. Hausman, Cambridge University Press, Cambridge 2002, p. 59-72.

${ }^{30}$ M. Friedman, The Methodology of Economics [in:] The Philosophy of Economics, ed. D. Hausman, Cambridge University Press, Cambridge 2008, pp. 145-178.

${ }^{31}$ C. Wilber, R. Hoksbergen, Ethical Values and Economics Theory: a Survey [in:] Economics, Ethics and Public Policy, ed. C. Wilber, Rowman \& Littlefield Publishers, Maryland 1998, pp.17-32.

${ }^{32}$ A.W. Coats, Half a century of methodological controversy in economics: as reflected by the writings of T.W. Hutchinson [in:] Methodological Controversy in Economics: Historical Essays in Honor of T.W. Hutchison, ed. A.W. Coats, JAI Press, Greenwich 1983, pp 1-42.

${ }^{33}$ T.H. Hutchinson, Positive Economics and Policy Objectives, Allen \& Unwin, London 1964.
} 
Since one of the arguments in favour of a value-free economic science is based on an approach to natural sciences, one of the most common criticism lies precisely in the very nature of the difference between economics and natural science, not only in scope, as maintained by Robbins and Friedman, but also in substance. Ascertaining whether society is the same as nature is indeed an ontological issue. Are there other structures in society which are not present in nature? Do they serve the same purpose as in nature? Authors have pointed out that the relationship established by economic researchers with their object of study is different from that of natural scientists, given that the objects observed by the social scientist have the attributes of consciousness, cognition, and volition. ${ }^{34}$ On the other hand, while the laws of the physical universe cannot be changed, social structures can be modified by human action. ${ }^{35}$

The theses of the neutrality of science have also been criticised by what some call 'naiff empiricism,' that is, the idea that there are also raw facts out there waiting to be studied by social scientists. Myrdal noted that:

Facts do not organize themselves into concepts and theories just by being looked at; indeed, except within the framework of concepts and theories, there are no scientific facts but only chaos. There is an inescapable a priori element in all scientific work. Questions must be asked before answers can be given. The questions are all expressions of our interest in the world; they are at bottom valuations. Valuations are thus necessarily involved already at the stage we observe facts and carry on theoretical analysis and not only at the stage when we draw political inferences from facts and valuations. ${ }^{36}$

Boulding supplies one of the most insightful criticisms of the idea of a neutral economic science. ${ }^{37}$ According to Boulding, a culture or subculture consists of a series of common values, that is, an ethics which enables the communication between the various group members. Society can be classified into cultures and subcultures because it is possible to identify groups who share common values. The scientific subculture is, therefore, characterised by a strong system of common values such as veracity, curiosity, measure, careful observation, experimentation, and objectivity. The epistemological process of science emerges because of a common structure of values. Similarly, the lack of a series of common values could explain why certain societies which, despite holding favourable conditions for the development of the scientific process, have failed to do so.

In its essence, science has an ethical underpinning. It should be noted that Boulding's argument presupposes that the elements which characterise the scientific subculture are not automatically considered good. To avoid this, an ethical stance must be adopted, in which case the economist is already conveying the

\footnotetext{
${ }^{34}$ R. Heilbroner, Economics as a Value Free Science, "Social Research" 1973, No. 40, pp. 129-143.

${ }^{35}$ R. Brandis, Value Judgments and Economics Science, "The Quarterly Review of Economics and Business" 1963, Vol. 3, No. 2, pp. 41-50.

${ }^{36}$ G. Myrdal, Objectivity in Social Research, Pantheon Books, London 1969, p. 9.

${ }^{37}$ K.E. Boulding, Economics as a Moral Science, “American Economic Review” 1969, Vol. 59, No. 1, pp. $1-12$.
} 
message that the pursuit of truth and objectivity is good in itself, even if trying to avoid economic, social or political considerations that require the expression 'ought to be.'

There are other arguments which pose serious threats to the perspective of value-free economics. One argument is associated with Heisenberg's uncertainty principle which, though initially conceived in the area of quantum mechanics, carries obvious repercussions for the whole of the scientific process. According to Heisenberg's principle, it is impossible to determine the position and momentum of a subatomic particle (for example, an electron) accurately, because human intervention will necessarily alter its velocity when trying to measure it. In short, observer and observed are not independent - when trying to obtain knowledge from a system by altering information inputs and outputs, the system is radically altered by those inputs and outputs. Therefore, ultimately, the laws of physics and other sciences (e.g. economics) are relative formulations, and to some extent the result of subjective perceptions, rather than objective certainties.

Furthering some of the conclusions of quantum physics, to which the issues of involvement and reflexivity addressed by critical sociology in the 1960s and 1970s can be added, it can be said that sciences are not only observing and studying the world, but indeed creating it. In this way, social scientists are also driving 'the bus they are studying., ${ }^{38}$ The image of the social scientist sitting in his office examining social reality is, at best, limited. Social scientists also produce reality. ${ }^{39}$ Boulding gave a highly illustrative example of this. Economists agree that, in general, the evolution of share prices in some financial markets is erratic and unpredictable. In order to predict prices in those markets, control must be put in place by way of implementing a counter-speculation system. The gold standard which regulated the international monetary system for decades is, to a certain extent, a good example. In Boulding's words, the conclusion is that as 'science moves from pure knowledge toward control, that is, toward creating what it knows, what it creates become a problem of ethical choice.' 40

\section{The values hidden in economic theory}

As previously explained, the neoclassical school aims to construct a positive, value-free science, a 'view from nowhere,' as in the title of Nagel's famous work. ${ }^{41}$ However, its premises and some of its primary principles are necessarily normative.

\footnotetext{
${ }^{38}$ G. Gutenschwager Is Economics a Value Free Science? World Economic Association, Conferences 2012, Economics and Society. The Ethical Dimension, https://weaethicsconference.files.wordpress. com/2012/03/gutenschwager_is-economics-a-value-free-science.pdf (accessed: September 16, 2014).

${ }^{39}$ Ibidem.

${ }^{40}$ K.E. Boulding, op. cit., p. 2.

${ }^{41}$ T. Nagel, The View from Nowhere, Oxford University Press, New York, Oxford 1989.
} 
The conception of the realm of neoclassical economics is based on the following premises: 1) individuals seek their personal interest 2) they are rational, know their own interests, and try to maximise them by choosing among existing alternatives 3) the purpose of human life is the pursuit of happiness, as defined by each individual, which implies freedom to attain it 4) the social world is comprised of individuals who compete against each other under conditions of scarcity in order to reach personal goals, and finally 5) there are natural mechanisms which lead economic agents to situations of balance. ${ }^{42}$

Although the issue here is not to discuss the degree of realism with which these premises are adopted, it is not difficult to acknowledge the normative nature of this conception of the world, and of the economic system. If the purpose of human life is the pursuit of happiness in a self-centred manner, in which case individuals need freedom to succeed, there is necessarily a vision of good across the whole of neoclassical economics. In fact, the statement that only self-preferred choices are considered individual wellbeing standards and that social wellbeing depends on the wellbeing of all individuals does not reflect an exemption of values.

However, neoclassical authors go even further by sustaining that the ideal economic situation results from a situation of balance of competitive markets, as it enables the fulfilment of the greatest number of individual desires. Once again, this stance also contains a value judgement, because it serves as an ideal by means of which the efficiency of economic conditions can be measured. If in a given economy markets are not competitive either due to state intervention or monopolies, these situations must be changed so that a higher level of efficiency and balance can be achieved.

Some of the developments of the neoclassical premises, to some degree, transposed to wellbeing economics, one of the most important branches of the discipline which uses microeconomic techniques to assess wellbeing. One of the best-known theorems is Pareto optimum or Pareto efficiency. According to this theorem formulated by Italian economist Vilfredo Pareto, an optimal situation is that in which, in a given allocation of goods, an individual's situation cannot be improved without making someone else worse off. From this idea, a Pareto improvement can also be inferred: social wellbeing improves when at least one person's wellbeing increases, without worsening anyone else's. In that case, as Sen noted, ${ }^{43}$ Pareto optimum can be applied to a situation in which people live in extreme poverty and others live in luxury if nobody's situation can be improved without making the wealthier worse off. Given that, Pareto optimum only refers to considerations of efficiency, omitting issues of redistribution, thus it becomes difficult to sustain that the theorem is value-free.

In fact, the most commonly used terms in the dominant branch of economics, such as 'productivity,' 'balance,' 'economic integration,' 'efficiency,' or 'adjustment' are also charged with the values associated with a utilitarian perspective of

${ }^{42}$ C. Wilber, R. Hoksbergen, op. cit., pp. 17-32.

${ }^{43}$ A. Sen, On Ethics and Economics, Blackwell Publishing, Malden 1988, pp. 31-40. 
economics ${ }^{44}$ whose tradition places its roots in Bentham. However, this is not the actual problem. Indeed, the real issue lies in the fact that the actual problem is not acknowledged by the authors who use it and present these theories as universal truths on which policies are based, thus failing to discuss the various perspectives of the problems.

\section{Final considerations}

As described above, the term 'economics' was used after the marginalist revolution with a view to removing all ideological weight from the discipline, thus presenting it as a pure, value-free science. The defence of a value-free economics is clearly linked to the pursuit of objectivity and to what Putnam called the last dogma of empiricism, that is, the belief that facts are objective and values subjective. ${ }^{45}$ Some even expressed the view that the term 'economics' should be limited to positive economics, and 'political economy' to normative economics. However, in light of the arguments presented herein, economics is necessarily moral and political.

If economics is the art of using necessary goods for domestic life and the Good Life, as defined by Aristotle, then it necessarily involves the definition of values which sustain the activities of use of provision. Therefore, economics is always moral. ${ }^{46}$ To state that economics is always moral does not mean that it should be incorporated into ethics. Ethics as a science focuses on the ethical problem in itself, and economics analyses the economic problem. The issue is that the economic problem cannot be detached from the ethical dimension. ${ }^{47}$

On the other hand, if the Good Life becomes complete in the community, where individuals find fulfilment in the pursuit of happiness, then economics is also political, as it involves a collective process, and not just a mere sum of individual preferences. In truth, economics cannot exist without the political dimension.

Political economy is, of course, also normative. But this leads to an important question: how can objectivity be pursued if it implies independent scientific results detached from the researcher's beliefs and values, it? Indeed, if facts and values are necessarily intertwined and the production of knowledge is permeated by the very existence of contextual values, then the pursuit of objectivity is irretrievably compromised.

\footnotetext{
${ }^{44}$ G. Myrdal, Implicit Values in Economics [in:] The Philosophy of Economics, ed. D. Hausman, Cambridge University Press, Cambridge 1984, pp. 250-259.

${ }^{45} \mathrm{H}$. Putnam, The Collapse of Fact/Value Dichotomy and Other Essays, Harvard University Press, Cambridge MA 2002.

${ }^{46}$ F. Louçã, C. Caldas., op. cit., p. 362.

${ }^{47}$ R. Crespo, op. cit.
} 
However, this may not be the case if intersubjective criticism is introduced, as advocated by Santos. ${ }^{48}$ Given that knowledge has a social dimension (that is, it is produced and reviewed by a collective of scientists) the effect of sustained beliefs as they may be, consciously or unconsciously, highly impregnated with normative considerations - can be controlled.

To this end, intellectual democracy must be promoted within the epistemic community, so that all social groups can get involved, especially those who are less socially represented, all the more because they are better positioned to identify the dominant values. Therefore, the greater the diversity of points of view, the stronger the possibility of attaining objective scientific research. ${ }^{49}$ Hence, objectivity should be a collective, non-hierarchical process open to debate, observation, and experiment. ${ }^{50}$

Educational institutions also play a pivotal role in promoting the pursuit of objectivity. Not only should educational programmes be designed with scientific results in mind, but they should also focus on the processes thereof; syllabuses and learning contents should be reformed in order to represent the diversity of social groups and societal values; science should be taught as being potentially uncertain, permeated by values and open to multiple perspectives.

\section{References}

Alvey J., A Short History of Economics as a Moral Science, "Journal of Markets \& Morality" 1999, Vol. 2, No. 1, pp. 53-73.

Aristotle, Nicomachean Ethics, Cambridge University Press, Cambridge 2000.

Aristotle, Politics, ed. B. Jowet, 1885, Online Library of Liberty, http://oll.libertyfund.org/ titles/579.

Blaug M., A Metodologia da Economia, Gradiva, Lisboa 1980.

Boulding K.E., Economics as a Moral Science, “American Economic Review” 1969, Vol. 59, No. 1, pp. 1-12.

Brandis R., Value Judgments and Economics Science, "The Quarterly Review of Economics and Business" 1963, Vol. 3, No. 2, pp. 41-50.

Caldas C., Beyond the Fact Value Split: Political Economy, communication presented at the conference 'The Revival of Political Economy: prospects for sustainable provision,' Universidade de Coimbra, October 23, 2010.

Caldas C., V. Neves, The meaning of objectivity. What can we learn from Robbins and Myrdal [in:] Values and Objectivity in Economics, eds. J. Caldas, V. Neves, Routledge, London 2012, pp. 47-63.

Coats A.W., Half a century of methodological controversy in economics: as reflected by the writings of T.W. Hutchinson [in:] Methodological Controversy in Economics: His-

\footnotetext{
${ }^{48}$ A. Santos, The facts and values of experimental economics [in:] Facts, Values and Objectivity in Economics, eds. J. Caldas, V. Neves, Routledge, London 2012, pp. 88-109.

${ }^{49}$ Ibidem, p. 94.

${ }^{50}$ C. Caldas, op. cit.
} 
torical Essays in Honor of T.W. Hutchison, ed. A.W. Coats, JAI Press, Greenwich 1983, pp 1-42.

Crespo R., On Aristotle and Economics, "Working Paper Series IAE" 2008, https://www.iae. edu.ar/pi/Documentos\%20Investigacin/Working\%20Papers/DTIAE08_2008.pdf.

Friedman M., The Methodology of Economics [in:] The Philosophy of Economics, ed. D. Hausman, Cambridge University Press, Cambridge 2008, pp. 145-178.

Gutenschwager G., Is Economics a Value Free Science?, World Economic Association, Conferences 2012, Economics and Society. The Ethical Dimension, https://weaethicscon ference.files.wordpress.com/2012/03/gutenschwager_is-economics-a-value-free-scien ce.pdf.

Heilbroner R., Economics as a Value Free Science, "Social Research” 1973, No. 40, pp. $129-143$.

Hume D., Treatise of Human Nature, Clarendon Press, Oxford 1888, http://michaeljohnson philo sophy.com/wp-content/uploads/2012/01/5010_Hume_Treatise_Human_Nature.pdf.

Hutchinson T.H, Positive Economics and Policy Objectives, Allen \& Unwin, London 1964.

Jevons W.S., The Theory of Political Economy, ed. Macmillan and Company, London 1888, Library of Economics and Liberty, http://www.econlib.org/library/YPDBooks/Je vons/jvnPE.html.

Keynes J.N. The Scope and the Method of Political Economy, Batoche Books, Kitchener 1990.

Louçã F., C. Caldas, Economia(s), Afrontamento, Porto 2010.

Malthus T., Definitions in Political Economy, ed. J. Murray, 1827, Online Library of Liberty, http://oll.libertyfund.org/titles/2255.

Marshall A., Principles of Economics, Macmillan, London 1961.

Marshall A., The Correspondence of Alfred Marshall [in:] Memorials of Alfred Marshall, ed. A.C. Pigou, Macmillan, London 1925, pp. 452-480.

Mill J.S., On the Definition and Method of Political Economy [in:] The Philosophy of Economics, ed. D. Hausman, Cambridge University Press, Cambridge 2008, pp. 41-58.

Myrdal G., Objectivity in Social Research, Pantheon Books, London 1969.

Myrdal G., Implicit Values in Economics [in:] The Philosophy of Economics, ed. D. Hausman, Cambridge University Press, Cambridge 1984, pp. 250-259.

Nagel T., The view from nowhere, Oxford University Press, New York, Oxford 1989.

Nunes A., Noção e objeto de Economia Politica, Almedina, Coimbra 2013.

Putnam H., The Collapse of Fact/Value Dichotomy and Other Essays, Harvard University Press, Cambridge MA 2002.

Ricardo D., Princípios de Economia Politica e Tributação, Fundação Calouste Gulbenkian, Lisboa 1983.

Ricardo D., The Works and Correspondence of David Ricardo, ed. P. Sraffa with the collaboration of M.H. Dobb, Cambridge University Press, Cambridge 1951-1973.

Robbins L., An Essay of Nature and Significance of Economic Science, Macmillan and Co., London 1945.

Santos A., The facts and values of experimental economics [in:] Facts, Values and Objectivity in Economics, eds. J. Caldas, V. Neves, Routledge, London 2012, pp. 88-109.

Sen A., On Ethics and Economics, Blackwell Publishing, Malden 1988. 
Senior N., An Outline of the Science of Political Economy, Augustus Kelley, London 1965.

Smith A., Teoria dos Sentimentos Morais, Martins Fontes, São Paulo 2012.

Smith A., A Riqueza das Nações, Fundação Calouste Gulbenkian, Lisboa 2001.

Weber M., Objectivity and Understanding in Economics [in:] The Philosophy of Economics, ed. D. Hausman, Cambridge University Press, Cambridge 2002, pp. 59-72.

Wilber C., R. Hoksbergen, Ethical Values and Economics Theory: A Survey [in:] Economics, Ethics and Public Policy, ed. C. Wilber, Rowman \& Littlefield Publishers, Maryland 1998, pp.17-32. 